\title{
Comparative Analysis of Current International Standards for Calculations Flanges Joint with Gasket Inside the Circle Location of the Bolt Holes
}

\section{GEORGETA ROMAN (URSE)*}

Politehnica University of Bucharest, Industrial Process Equipment Department, 313 Splaiul Independentei, 060042, Bucharest, Romania

Abstract: This paper presents the comparative analysis of the existing international normative calculation (EN 13445-3 European, ASME-Code, Section VIII, British Standard (PD 5500: 2009)) on the flange gasket joint situated inside the circle location of the bolt holes. The comparative analysis was performed for the same type of flange. The paper presents a comparative study of American and European standard, in terms of cost of production for the pressure equipment to assess the strengths and weaknesses of these regulations.

Keywords: flange joint, gasket

\section{Introduction}

Why did I started comparative analysis for the standards? Because the analysis performed in specialized literature [1] it was found that there may be differences between the normative technically and economically. In the [1] study the analysis was performed for nine pressure Vessels to show technical and economic advantages or disadvantages for applying standards (EN 13445 DBF, ASME VIII Division 1 (Code stamp), ASME VIII Division 1 (CE)). The result is clear: for at least the same safety level the European standard EN 13445 enables in many cases a more cost-effective production of pressure equipment than the American ASME Boiler \& Pressure Vessel Code [1].

In ASME the costs of materials and production are higher than those resulting from the use of EN 13445 because of higher wall thickness, heat treatment applied after welding [1].

These results are presented in

Table 1 where the abbreviation DBF means design according to formulas, the abbreviation DBA means design according to stress analysis.

Also, an analysis of the current norms, in which their shortcomings were highlighted, was carried out in the specialized publications [2 - 5].

Table 1

Comparing results with international standard in terms of production costs [1]

\begin{tabular}{|c|c|c|c|c|c|c|}
\hline Vessel /Code & $\begin{array}{c}\text { EN 13445 } \\
\text { DBF (CE) }\end{array}$ & $\begin{array}{c}\text { EN 13445 } \\
\text { DBA (CE) }\end{array}$ & $\begin{array}{c}\text { ASME VIII } \\
\text { Division 1 } \\
\text { (Code stamp) }\end{array}$ & $\begin{array}{c}\text { ASME VIII } \\
\text { Division 1 } \\
\text { (CE) }\end{array}$ & $\begin{array}{c}\text { ASME VIII } \\
\text { Division 2 } \\
\text { (Code stamp) }\end{array}$ & $\begin{array}{c}\text { ASME VIII } \\
\text { Division 2 } \\
\text { (CE) }\end{array}$ \\
\hline $\begin{array}{c}\text { Natural gas } \\
\text { storage tank }\end{array}$ & $100,0 \%$ & $95,6 \%$ & $130,4 \%$ & $138,5 \%$ & $118,1 \%$ & $117,9 \%$ \\
\hline $\begin{array}{c}\text { Hydrogen } \\
\text { reactor } \\
\text { (welded } \\
\text { course) }\end{array}$ & $100,0 \%$ & - & $115,9 \%$ & $122,8 \%$ & $106,5 \%$ & $110,5 \%$ \\
\hline
\end{tabular}

*email:ursegeanina@yahoo.com 


\begin{tabular}{|c|c|c|c|c|c|c|}
\hline Vessel /Code & $\begin{array}{l}\text { EN } 13445 \\
\text { DBF (CE) }\end{array}$ & $\begin{array}{l}\text { EN } 13445 \\
\text { DBA (CE) }\end{array}$ & $\begin{array}{c}\text { ASME VIII } \\
\text { Division } 1 \\
\text { (Code stamp) }\end{array}$ & $\begin{array}{l}\text { ASME VIII } \\
\text { Division } 1 \\
\text { (CE) }\end{array}$ & $\begin{array}{c}\text { ASME VIII } \\
\text { Division } 2 \\
\text { (Code stamp) }\end{array}$ & $\begin{array}{l}\text { ASME VIII } \\
\text { Division } 2 \\
\text { (CE) }\end{array}$ \\
\hline $\begin{array}{l}\text { Hydrogen } \\
\text { reactor } \\
\text { (forged } \\
\text { course) } \\
\end{array}$ & $100.0 \%$ & - & $94.3 \%$ & $94.9 \%$ & $84.9 \%$ & $85.3 \%$ \\
\hline Autoclave & $100.0 \%$ & - & $97.9 \%$ & $98.6 \%$ & - & - \\
\hline $\begin{array}{c}\text { Stirring } \\
\text { vessel } \\
\text { (Impeller } \\
\text { type mixer) } \\
\end{array}$ & $100.0 \%$ & - & $110.6 \%$ & $110.6 \%$ & - & - \\
\hline $\begin{array}{c}\text { AES } \\
\text { heat } \\
\text { exchanger }\end{array}$ & $100.0 \%$ & - & $100.3 \%$ & $101.8 \%$ & - & - \\
\hline $\begin{array}{c}\text { BEM } \\
\text { heat } \\
\text { exchanger }\end{array}$ & $100.0 \%$ & - & $99.0 \%$ & $101.9 \%$ & - & - \\
\hline $\begin{array}{c}\text { NEN } \\
\text { heat } \\
\text { exchanger }\end{array}$ & $100.0 \%$ & - & $108.2 \%$ & $106.9 \%$ & - & - \\
\hline $\begin{array}{c}\text { Water } \\
\text { separator }\end{array}$ & $100.0 \%$ & - & $105.6 \%$ & $110.1 \%$ & - & - \\
\hline $\begin{array}{c}\text { Header of an } \\
\text { air-cooler }\end{array}$ & $100.0 \%$ & $88.1 \%$ & $106.7 \%$ & $108.2 \%$ & - & - \\
\hline
\end{tabular}

The comparative analysis of current international normative calculation was made for joint flanges with gasket located inside the circle on which are located tensioning bolts for the gasket (Error! Reference source not found.).inside the circle on which are located tensioning bolts for the gasket (Figure 1).

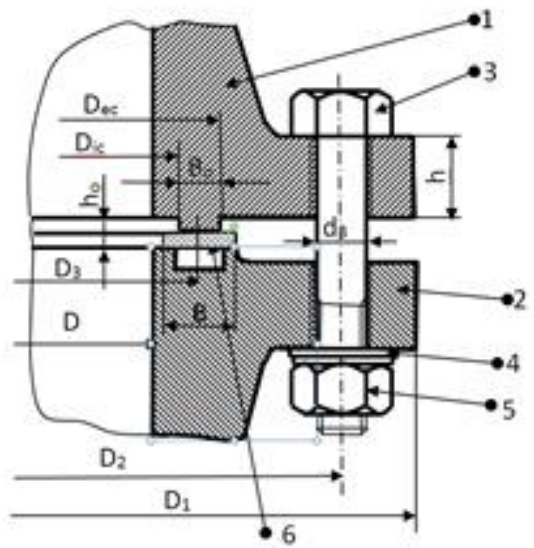

Figure 1. The flange gasket inside the circle location holes for bolts

[6 -8]:1,2 - flanges; 3 - bolt; 4 - washer; 5 - nut; 6 - gasket

The current official calculation methods for calculation of flanged joints of pressure vessels [9- 11] contain the strength calculation which includes the choice of gasket; it intervenes only in the calculation of resistance. No references are made to the necessary rigidity of the flange joint or the issue of their sealing.

The calculations are made for:

-strain static state in operating conditions at calculation parameters under the pressure test of the assembly. In all the calculations are considered that flanges and bolts temperatures are equal, but inferior to the creep temperature;

-the fatigue loading with consideration of linear-elastic behavior of the material of which the flanges and bolts are constructed.

\section{Flanges joint calculation for situations covered by the official standards}

The calculation according to the standards [9-11] is based on the following assumptions: 
- treats the flanges joint for gasket are arranged inside bolt circle $\left(\mathrm{d}_{\mathrm{g} \text {,ext }}<\mathrm{D}_{2}\right)$;

- the flanges bend under the influence of moments with flanges according to normative refers on only two cases, namely: - at environment condition, $\mathrm{T}=\mathrm{T}_{0}$ and $\mathrm{P}=\mathrm{P}_{0} ;-$ in operating condition at $T=T_{s}$ and $P=P_{c}\left(P_{c}\right.$ - the calculation pressure, $T_{s}$ - the bolt temperature), but at temperatures below the creep temperature.

In terms of the calculation both European and BS norms, flanges are divided into integral type, optional type flanges, loose hubbed type and loose flanges according to Table 2, and the ASME Code [0] classification is more detailed. They are assigned to either type integral flanges or loose flange type.

Table 2

Types of flanges foreseen in the normatives $[0-0]$

\begin{tabular}{|c|c|c|c|}
\hline $\begin{array}{l}\text { Flanges } \\
\text { Type }\end{array}$ & ASME Code, Section VIII & EN 13445-3:2002 & British Standard (PD 5500:2009) \\
\hline Integral & Fig. 1. Integral Type Flange with a & $\begin{array}{c}\text { Fig. } 1 \\
e=t \\
\text { where: } \\
e-\text { flange thickness }\end{array}$ & $\begin{array}{c}\text { Idem } \\
N \text { - gasket contact width, } \mathrm{N}=0.0 \\
\text { for self-energizing gaskets }\end{array}$ \\
\hline Optional & Fig. 2. Loose Type Flange Without a & $\begin{array}{c}\text { Fig. 2 } \\
e=t \\
\text { where: }\end{array}$ & $\begin{array}{l}\text { Idem } \\
N \text { - gasket contact width, } \mathrm{N}=0.0 \\
\text { for self-energizing gaskets } \\
\text { whig. 2 }\end{array}$ \\
\hline
\end{tabular}




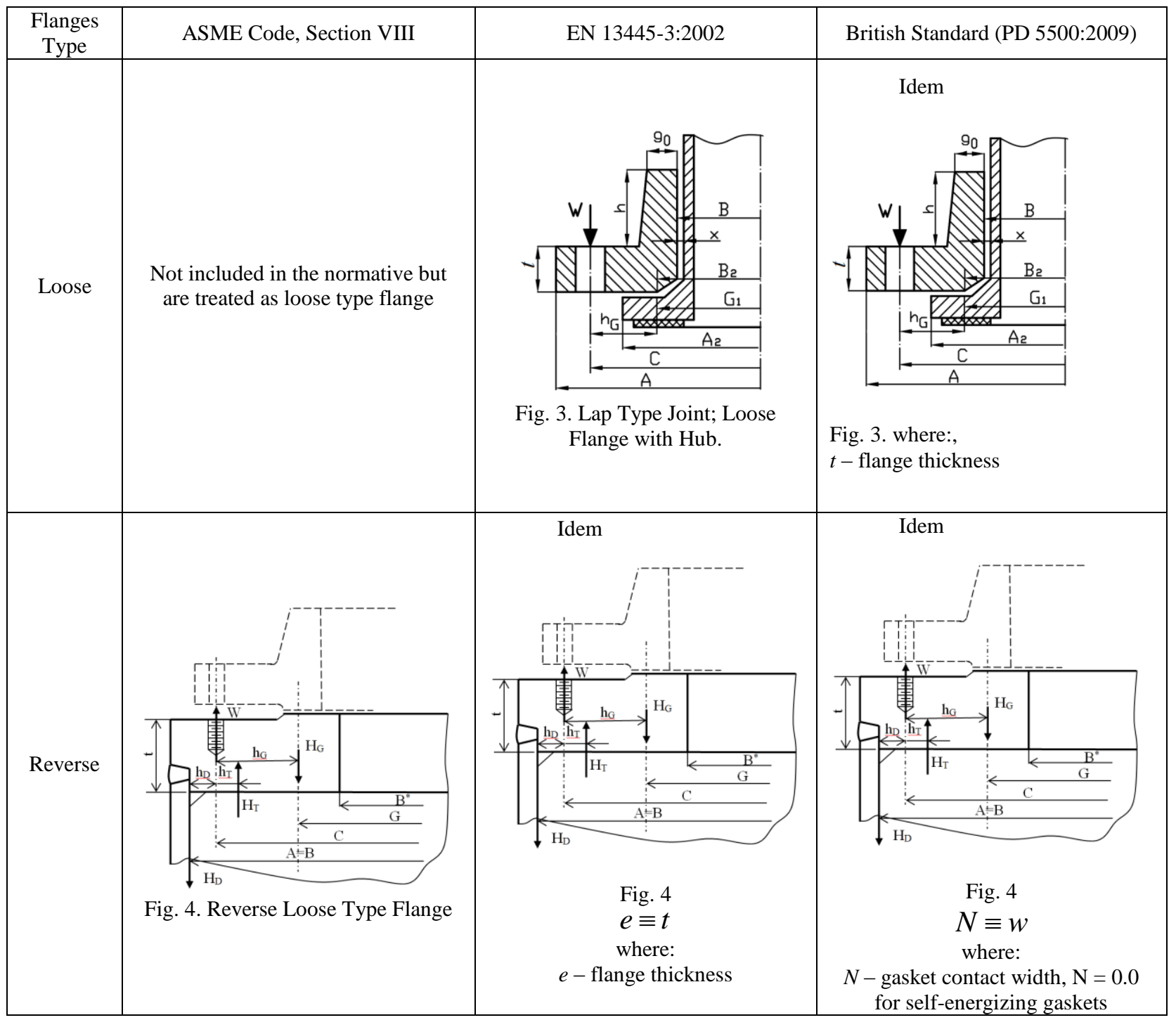

Table 3 contains calculation relations for forces, bending moments and meridional stress according to the norms EN 13445-3, ASME-Code, Section VIII, and British Standard (PD 5500:2009).

Table 3

Table for relations calculation according to Applicable standards [0 - 0]

\begin{tabular}{|c|c|c|c|}
\hline Codes & ASME Code, Section VIII & EN 13445-3:2002 & $\begin{array}{l}\text { British Standard } \\
\text { (PD 5500:2009) }\end{array}$ \\
\hline Forces & 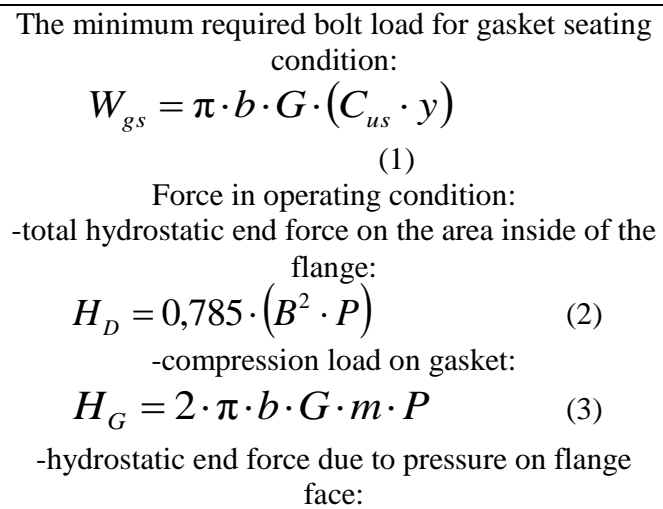 & $\begin{array}{c}\text { Idem ASME } \\
\text { Code, Section } \\
\text { VIII, } \\
W_{A} \equiv W_{g s} \\
\text { where: } \\
W_{A}-\text { the } \\
\text { minimum } \\
\text { required bolt load } \\
\text { for gasket seating }\end{array}$ & $\begin{array}{c}\text { Idem ASME Code, } \\
\text { Section VIII, } \\
W_{m 2} \equiv W_{g s} \\
\text { where: } \\
W_{m 2}-\text { the } \\
\text { minimum required } \\
\text { bolt load for gasket } \\
\text { seating }\end{array}$ \\
\hline
\end{tabular}




\begin{tabular}{|c|c|c|c|}
\hline Codes & ASME Code, Section VIII & EN 13445-3:2002 & $\begin{array}{l}\text { British Standard } \\
\text { (PD 5500:2009) }\end{array}$ \\
\hline & $\begin{aligned} \mathrm{H}_{\mathrm{T}}= & H-H_{D} \\
& - \text { total hydrostatic end force: } \\
H= & 0,785 \cdot\left(G^{2} \cdot P\right)\end{aligned}$ & & \\
\hline $\begin{array}{l}\text { Bending } \\
\text { moments } \\
\text { meridional }\end{array}$ & $\begin{array}{l}\text { The moment of the flange at initial load: } \\
\begin{array}{c}M=\mathrm{M}_{\mathrm{A}} \cdot \frac{C_{u s}}{B_{s c}} \\
\mathrm{M}_{\mathrm{A}}=W \cdot h_{G}\end{array} \\
\text { The moment in operating condition for Integral } \\
\text { Type Flanges: } \\
\text {-displacement: } \\
\mathrm{M}_{\mathrm{D}}=H_{D} \cdot\left[\frac{C-\left(B+g_{1}\right)}{2}\right] \\
\mathrm{M}_{\mathrm{G}}=H_{G} \cdot\left[\frac{C-G}{2}\right) \\
\text { - additional due to the pressure on the flange } \\
\text { surface, } \\
\mathrm{M}_{\mathrm{T}}=H_{T} \cdot\left[\frac{C}{2}-\frac{(B+G)}{4}\right] \\
\text {-the total moment acting upon flange for operating } \\
\text { condition, } \\
M=M_{o} \cdot \frac{C_{u s}}{B_{s c}} \\
M_{o}=M_{D}+M_{G}+M_{T}\end{array}$ & $\begin{array}{c}\text { Idem ASME } \\
\text { Code, Section } \\
\text { VIII, } \\
\mathrm{M}_{\text {op }} \equiv \mathrm{M}_{\mathrm{o}} \\
\text { where: } \\
\mathrm{M}_{\text {op }}-\text { total } \\
\text { moment acting } \\
\text { upon flange for } \\
\text { operating } \\
\text { condition }\end{array}$ & $\begin{array}{l}\text { Idem ASME Code, } \\
\text { Section VIII, } \\
\mathrm{M}_{\mathrm{op}} \equiv \mathrm{M}_{\mathrm{o}} \\
\text { where: } \\
\mathrm{M}_{\mathrm{op}}-\text { total } \\
\text { moment acting upon } \\
\text { flange for operating } \\
\text { condition }\end{array}$ \\
\hline Stress & $\begin{array}{l}\text { 1. Integral Type Flange or Loose Type Flange with } \\
\text { a Hub: } \\
\qquad \begin{array}{c}\text { a) Flange hub stress: } \\
S_{H}=\frac{f \cdot M_{o}}{L \cdot g_{1}^{2} \cdot B} \\
\text { b) Flange radial stress: } \\
S_{R}=\frac{(1,333 \cdot t \cdot e+1)}{L \cdot t^{2} \cdot B} \\
\text { c) Flange tangential stress: } \\
S_{T}=\frac{Y \cdot M_{o}}{t^{2} \cdot B}-Z \cdot S_{R} \\
2 . \text { Loose Type Flange without a Hub: } \\
\text { a) Longitudinal and radial flange hub stress: } \\
S_{R}=S_{H}=0 \\
\text { c) Flange tangential stress: } \\
S_{T}=\frac{Y \cdot M_{o}}{t^{2} \cdot B} \\
\text { 3. Reverse Integral Type Flange or Reverse Loose } \\
\text { Type Flange with a Hub: } \\
\text { a) Longitudinal hub stress: } \\
f \cdot M_{o} \\
S_{H}=\frac{{ }^{2}}{L_{r} \cdot t^{2} \cdot B}\end{array}\end{array}$ & $\begin{array}{c}\text { Idem ASME } \\
\text { Code, Section } \\
\sigma_{z} \equiv S_{H} \\
\text { VIII, } \sigma_{r} \equiv S_{R} \\
\sigma_{\theta} \equiv S_{T} \\
\text { where: } \\
\sigma_{z}-\text { flange hub } \\
\text { stress; } \\
\sigma_{r}-\text { flange } \\
\text { radial stress; } \\
\sigma_{\theta}-\text { flange } \\
\text { tangential stress; }\end{array}$ & $\begin{array}{l}\text { Idem ASME Code, } \\
\text { Section VIII. }\end{array}$ \\
\hline
\end{tabular}




\begin{tabular}{|c|c|c|c|}
\hline Cades & ASME Code, Section VIII & EN 13445-3:2002 & $\begin{array}{l}\text { British Standard } \\
\text { (PD 5500:2009) }\end{array}$ \\
\hline & $\begin{array}{l}\text { b) Flange radial stress: } \\
S_{R}=\frac{\left(1,333 \cdot t \cdot e_{r}+l\right) \cdot M_{o}}{L_{r} \cdot g_{1}^{2} \cdot B^{*}} \\
\text { c) Flange tangential stress: } \\
S_{T 1}=\frac{Y_{r} \cdot M_{o}}{t^{2} \cdot B^{*}}-\frac{Z \cdot S_{R} \cdot\left(0,67 \cdot t \cdot e_{r}+1\right)}{\left(1,33 \cdot t \cdot e_{r}+1\right)} \\
S_{T 2}=\left[Y-\frac{2 \cdot K^{2}\left(0,67 \cdot t \cdot e_{r}+l\right)}{\left(K^{2}-l\right) \cdot L_{r}}\right] \cdot \frac{M_{o}}{t^{2} \cdot B^{*}} \\
\text { 4. Reverse Loose Type Flanges without a Hub: } \\
\text { a) Longitudinal and radial flange hub stress: } \\
S_{R}=S_{H}=0 \quad \begin{array}{c}\text { c) Flange tangential stress: } \\
S_{T}=\end{array} \\
\frac{Y \cdot M_{o}}{t^{2} \cdot B^{*}}\end{array}$ & & \\
\hline
\end{tabular}

The nomenclature for

Table 2 and Table 3:

$A$ - outside diameter of the flange or, where slotted holes extend to the outside of the flange, the diameter to the bottom of the slots;

$b$ - effective gasket contact width;

$B$ - inside diameter of the flange;

$B^{*}$ - inside diameter of the reverse flange;

$B_{s c}$ - bolt spacing correction factor;

$b_{0}$ - basic gasket seating width;

$C$ - bolt circle diameter;

$e, L,-$ flange stress factor;

$e_{r}, L_{r}$ - flange stress factor $e$ for a reverse type flange;

$G$-diameter at the location of the gasket load reaction;

$g_{1}-$ thickness of the hub at the large end;

$g_{o}-$ thickness of the hub at the small end;

$h$ - hub length;

$h_{D}-$ moment arm for load $H_{D}$;

$h_{G}-$ moment arm for load $H_{G}$;

$h_{T}$ - moment arm for load $H_{T}$;

$K$ - ratio of the flange outside diameter to the flange inside diameter;

$P$ - design pressure;

$t$ - flange thickness;

$w$ - width of the nubbin;

$Z, Y$ - flange stress factor;

$C_{u s} \equiv C_{F} ; \beta_{T} ; \beta_{U} ; \beta_{Y} ; \beta_{Z} ; \lambda$ and $d$ are corrections factors according to EN 13445-3 [11].

\section{Conclusions regarding the calculation of flanged joints based on current normative}

In Table 3, we centralized the formulas for flanged joints according to current standards [9-11], it is found that: 
- there are no calculation differences between relationship: forces and bending moments; calculating the stress; calculating allowable stress;

- but there are the following differences: standards using different symbols regarding forces, bending moments, stress, length, correction factors, etc. ASME norm also do not treat loose flanges type but only those integral type and optional;

The current normative provide calculations for flanges, bolts and gaskets only for $\Delta T_{f s}=0$.

When calculating fatigue life currently in normative, the Palmgren - Miner rule is recomanded,

$$
\sum_{i}\left(\frac{n}{N}\right)_{i}=C
$$

where $C$ has values as follows:

○ in ASME Code, $C=1$; in EN 13445, $C=0.8$; 0.4 or 0.3 ; in BS $5500, C=0.8 ; 0.4$ or 0.3 .

In this relationship is not taken into consideration:

- mean stress influence but only the amplitude stress;

- residual stress influence;

- the damage caused by the influence of various external factors.

\section{- Proposals:}

$\mathbf{1}$ - it is necessary to supplement existing normative by introducing:

- the effect of temperature difference $\Delta T_{f s} \neq 0$, to the strength and tightness;

- influence of flange rigidity regarding tightness.

In papers [7; 12] the problem of the influence of $\Delta T_{f s}$ in normal operating and transitory regime was solved and can be used;

$\mathbf{2}$ - it is suggested to use the V. V. JINESCU relationship [13], for calculation the fatigue life:

$$
\sum_{i}\left(\frac{n}{N}\right)_{i}^{\frac{\alpha+1}{m}}=C_{\sigma},
$$

where;

$$
C_{\sigma}=1-\left(\frac{\sigma_{m}}{\sigma_{u}}\right)^{\alpha+1} \cdot \delta_{\sigma_{u}}-\left(\frac{\sigma_{r e s}}{\sigma_{u}}\right)^{2} \cdot \delta_{\sigma_{r e s}}-D_{T},
$$

with $\mathrm{k}=0.16 \ldots 1.0$ and $m=3 \ldots 5$ - for various steels [13]. $D_{T}$ is the deterioration, dimensionless with values $D_{T} \in(0 ; 1]$.

$\alpha, m$-constants of material; $\alpha=1 / k$, becomes from nonlinear material behavior law,

$$
\sigma=\mathbf{M}_{\sigma} \cdot \varepsilon^{k},
$$

where $\mathrm{M}_{\sigma} ; k$-constants; $\sigma$ - normal stress; $\varepsilon$ - strain.

Generally, $\alpha=0$ - through the shock loading and $\alpha=1$ for linear-elastic behavior under monotonic loading;

$\sigma_{m}$ - mean stress; $\sigma_{u}-$ ultimate stress; $\sigma_{r e s}$ - residual stress; $D_{T}$ - deterioration or damage.

In the case of a sample without residual stresses $\left(\sigma_{\text {res }}=0\right)$ and undeteriorated $D_{T}=0$ [13]:

$C_{\sigma}=1$, for alternating symmetrical loading $(R=-1)$ when $\sigma_{m}=0$;

$C_{\sigma}<1$, if $\sigma_{m}>0$ and $C_{\sigma}>1$, if $\sigma_{m}<0(R \neq-1)$.

$\circ$ in the case of a sample without residual stresses $\left(\sigma_{\text {res }}=0\right)$ but cracked and pre-loaded sample (when $D_{T} \neq 0$ ): $C_{\sigma}=C_{\sigma}(n)<1$, for alternating symmetrical loading $(R=-1)$;

$C_{\sigma}<1$ or $C_{\sigma}>1$ in the general case $(R \neq-1)$. 
Calculation of fatigue flanges according to the standards is incomplete and is necessary to be taken into consideration the effect of mean stress, residual stresses and deterioration. This is found only in the relationship proposed in the paper [13].

\section{Deterioration and residual stresses}

The deterioration of weldements due to flaws or cracks, as well as the residual stresses in the heat affected zone may reduce the strength of the flange joint.

As to take into consideration the:

-deterioration and the residual stresses one calculates the critical stresses, $\sigma_{c r}$, with the relations proposed in the papers [14-18];

-superposition of different loads one may use the results reported in the papers [19-25];

-fatigue of flanges joint due to pressure or/and temperature fluctuations is usefull to consider the relationships proposed in the papers [26-30].

\section{Conclusions}

In the current international normative [9-11], the calculation of the flange joints with gasket situated inside the circle location of the bolts holes refers only to static load, operating condition and pressure test.

It is necessary to complete the current normative by introducing: the effect of the temperature difference between the flange and the bolts, $\Delta T f s \neq 0$, on the strength and sealing and the influence of the rigidity of the flange on the sealing. A new method of evaluating the strength of flanged joints on the basis of the principal of critical energy is proposed, in which - unlike everything that has been proposed so far - the influence of deterioration and residual stresses are introduced.

\section{References}

1.*** The European Confederation of Organizations for Testing, Inspection, Certification and Prevention Comparative Study on Standards for Pressure Equipment EU versus USA, CEOC, Bulletin supplement, no. 17, 2014, Brussels, Belgium, 2014, p. 5-6.

2.IATAN I. R., ROMAN (URSE) G., Considerations about Flange with Ring Gasket.The sealing pressure, Rev. Chim., 60, (11), 2009, 1119

3.JINESCU V.V., URSE G., CHELU A., Evaluation and completion the design methods of pressure vessels flange joints, Rev. Chim., 69, (8), 2018, 1956

4.URSE, G., DURBACA, I., PANAIT, I.C., Some research results on the tightness and strength of flange joints, in: Journal of Engineering Sciences and Innovation, 3, Issue 2, 2018, p 107-130.

5.JINESCU V.V., CHELU A., NICOLOF V.I., ROMAN (URSE) G., Strength analysis of shells on the basis of principle of critical energy, Buletin Stiintific U.P.B, Seria D, Vol. 81, Iss. 3, 2019, p 155 - 168, ISSN 1454-2358. 6.JINESCU V.V., TEODORESCU N., Constructia si calculul imbinarilor cu flanse. I, Rev. Chim., 32, (3), 1981, 286

7.JINESCU V.V., Utilaj tehnologic pentru industrii de process, vol. 3, Editura Tehnica, Bucharest, 1988.

8.JINESCU V.V., TEODORESCU, N., Constructia si calculul imbinarilor cu flanse (II), Rev. Chim., 32, (4), 1981, 385

9.***ASME Boiler and Pressure Vessel Code. Section VIII, Division 2, Rules for construction of pressure vessels, 2010.

10.***British Standard BS, PD 5500: 2009.

11.***Pressure Vessel Design European Standard EN 13445 - 3, 2009.

12.JINESCU V.V., TEODORESCU N., Constructia si calculul imbinarilor cu flanse (III), Rev. Chim., 33, (7), 1982, 671

13.JINESCU V.V., Critical energy approach for the fatigue life calculation under blocks with different normal stresses amplitudes, I. J. of Mechanical Sci., vol. 67, 2013, p 78 - 88.

14.JINESCU V.V., NICOLOF V.I., TEODORESCU N., Relation for Calculation of Critical Stresses in Pressure Equipment with Cracks, Rev. Chim., 64, (8), 2013, 858 
15.JINESCU V.V., Prediction of the influence of Residual Stresses to Strength and Lifetime of Process Equipment, Rev. Chim., 60, (11), 2009, 114

16.JINESCU V.V., Tratat de Termomecanica, vol. 1, Editura AGIR, Bucharest, 2011.

17.JINESCU V.V., JINESCU G., - Durata de viata a structurilor tehnice si a organismelor vii, Editura "Tehnica - Info", Chisinau, 2018.

18.JINESCU V.V., NICOLOF V.I., CHELU A., MANEA A.E., Calculation of the local critical state taking into account the deterioration and the residual stresses, J. Eng. Sci. and Innovation, 2 (Issue 3), 2017, 9 - 21.

19.JINESCU V.V., CHELU A., ZECHERU GH., ALEXANDRU PUPAZESCU AL., SIMA T., DRAGHICI GH.,

The influence of loads superposition, deterioration due to cracks and residual stresses on the strength of tubular junction, Rev. Chim., 68, (6), 2017, 1365

20.JINESCU V.V., MANEA S.E., JINESCU C., The result of loads superposition upon the matter and particularity upon the environment, Rev. Chim., 68, (4), 2017, 656

21.JINESCU V.V., TEODORESCU N., JINESCU G., PANAIT I.C., The result superposition of different actions upon the mechanical structures and living organisms, Rev. Chim., 67, (12), 2016, 2607

22.JINESCU V.V., CHELU A., TEODORESCU N., NICOLOF V.I., Strength of tubular samples and tubular cracked junctions under combined loads, , Rev. Chim., 66, (11), 2015, 1832

23.JINESCU V.V., NICOLOF V.I., JINESCU C., CHELU A., Superposition of Effects in Calculating the Deterioration of Tubular Structures and in Non-newtonian Fluid Flow, Rev. Chim., 66, (5), 2015, 698

24.JINESCU V.V., Energonica, Editura Semne, Bucharest, 1997.

25.JINESCU V.V., Energia, Energonica si Termodinamica, Editura AGIR, Bucharest, 2016.

26.JINESCU V.V., NICOLOF V.I., TEODORESCU N., Effects superposition under imposed deterioration and simultaneous fatigue in different regimes, Int. J. Damage Mech., 26 (Issue 5), 2017, p. 633-650.

27.JINESCU V.V., Fatigue life prediction for simultaneous cyclic loading with blocks of normal stresses and shear stresses, J. Eng. Sci. and Innovation, 1, nr. 1, 2016, pp. 1-16.

28.JINESCU V.V., Cumulation of Effects in calculation the Deterioration of Fatigue loaded Structures, I. J. Damage Mech., 21, July, 2012, p. 671-695.

29.JINESCU V.V., Applications in Mechanical Engineering of the Principle of Critical Energy, Lambert Academic Publishing, Saarbrucken, 2015.

30.JINESCU V.V., Fatigue Life of the Process Equipment Made of Nonlinear Materials, Rev. Chim., 63, (1), 2012,98

Manuscript received: 21.01.2020 